\title{
Effect of Apamarga Kshara Taila Uttarbasti in the Management of Infertility w.s.r. Tubal-blockage
}

\section{Research article}

\author{
Rajput Shivshankar $\mathrm{A}^{1^{*}}$, Mata Shweta ${ }^{2}$, Dei $\mathrm{LP}^{3}$, Donga SB ${ }^{4}$, Shaikh Nilofar ${ }^{5}$ \\ 1 PG Scholar, 3 HOD \& Prof., 4. Associate Professor, 5. PG Scholar, \\ Department of Striroga and Prasuti Tantra \\ 2. PG Scholar, Department of Shalakya Tantra, \\ Institute for Post Graduate Teaching \& Research in Ayurveda, Gujarat Ayurved University, \\ Jamnagar-361008, Gujarat, India.
}

\begin{abstract}
Infertility is the most sensitive and cumbersome problem which haunts every couple. The major cause in infertility is female factor which is $30.20 \%$. Among female factor the sub factors are ovarian, tubal, endometrial and uterine. Female Infertility due to tubal blockage is the $2^{\text {nd }}$ most contributing factor, in $30 \%$ of the cases. So for this study, we considered only tubal infertility and to make a pin-pointed assessment criteria. The criteria for selection of patients and assessment of results were unilateral or bilateral tubal blockage diagnosed in hysterosalpingography (HSG). Thus 18 patients in the age group of 20-40 years were registered for the study, with $75 \%$ primary infertility and $25 \%$ secondary infertility. Of these patients 16 completed the course of treatment. Patients having acute pelvic infection, hypersensitivity to chemical dye, congenital anomalies of vulva \& vagina, CA cervix, STD or any debilitating diseases like T.B. were excluded. Apamagra Kshara Taila was selected for its Vata-Kapha Shamaka and Lekhana properties. The dose of Uttar Basti was $5 \mathrm{ml}$ with duration of two consecutive cycles at the interval of three days. The tubal blockage was removed in $75 \%$ of the patients and $25 \%$ of the patients had conceived within the follow-up period of two months. The results suggest that Uttar Basti is a safer, cost effective and highly significant Ayurvedic treatment modality for tubal-blockage, with no apparent complications.
\end{abstract}

Key words: Apamarga Kshara Taila, HSG, Tubal-blockage, Uttar Basti.

\section{Introduction:}

Infertility is a very vast topic and the treatment is becoming rich day by day with technological advancements. Infertility is defined as the inability of a couple to achieve conception after one

\section{*Corresponding Author:}

\section{Rajput Shivshankar}

PG Scholar,

Dept. of Stree Roga \& Prasuti Tantra, IPGT \& RA, Gujarat Ayurved University, Jamnagar, Gujarat, India.

E. Mail: shivshankerdr@gmail.com

Mob: +91-9428411160 year or more than 1 year of regular and unprotected coitus. The major cause in infertility is female factor which is $30.20 \%$. Female factors are ovarian, tubal, endometrial and uterine. Female Infertility due to tubal blockage is the $2^{\text {nd }}$ most contributing factor, in $30 \%$ of the cases (1). The only options left for a couple suffering from Tubal Infertility are either Reconstructive Tubal Surgery or In Vitro Fertilization and Embryo Transfer (IVFET). Both the procedures are time taking, invasive and more so, not always within the financial affordability of the majority of population in India. In Ayurvedic 
classics, Uttarbasti is an important Ayurvedic procedure, which is defined in very descriptively. The procedure was selected as a method of drug administration in case of tubal blockage for the present study. Apamagra Kshara Taila was selected for its Vata-Kapha Shamaka and Lekhana properties.

\section{Aims \& Objectives:}

1) To evaluate the efficacy of trial drug i.e. Apamargakshara Taila Uttarabasti in Tubal blockage.

2) A study of the complications, if any, during and after the course of treatment.

\section{Materials and Methods:}

The Patients were selected from the O.P.D \& I.P.D. of Stree Roga and Prasuti Tantra and referred from other Dept. I.P.G.T. \& R.A., Gujarat Ayurved University, Jamnagar.

\section{Inclusion Criteria:}

Patients of child bearing age (20$40 \mathrm{yrs}$ ) and also having history of active marital life more than 1 year, diagnosed on the basis of hysterosalpingogram (HSG) were registered for the study.

\section{Exclusion Criteria:}

Patients having acute pelvic infection, hypersensitivity to chemical dye, congenital anomalies of vulva \& vagina, carcinoma cervix, sexually transmitted disease (STD) or any debilitating disease like tuberculosis (TB) were excluded from the study.

\section{Registration of patients:}

A total of 18 patients were registered and 16 patients completed the course of treatment. Two patients had to discontinue the treatment due to personal family problems.

\section{Investigations:}

To rule out any other pathology routine hematological and urinary analysis were done before and after the treatment. Especially investigations HIV (Human Immunodeficiency Virus), HBsAg (Australia antigen for hepatitis B) \& VDRL (Venereal Disease Research Laboratory), were also done in all patients.

\section{Parameters of diagnosis \& assessment of results}

Patients were selected on the basis of hysterosalpingography (HSG) with the report of unilateral or bilateral tubal blockage. No patient was incorporated for study with the report of laparoscopic chromopertubation, as the chances of false reports are there. A scoring pattern was adopted to analyze for Artavakshaya Lakshana.

\section{Scoring Pattern for the associated} factors

- Yathochitakala Adarshana (Oligomenorrhoea)

$$
\begin{aligned}
& 0 \text { - 22-35 days } \\
& 1 \text { - 36-45 days } \\
& 2 \text { - > 45 days }
\end{aligned}
$$

- Alpata (Hypomenorrhoea)

$$
\begin{aligned}
& 0-3-5 \text { days } \\
& 1-2 \text { days } \\
& 2-<2 \text { days } \\
& 3-\quad \text { Spotting }
\end{aligned}
$$

- Yoni Vedana (Dysmenorrhoea)

0 - No pain

1 - Bearable pain

2 - Requirement of oral analgesic

3 - Requirement of injectable analgesic

\section{Selection of the drug:}

Tubal-blockage was considered as a Vata-Kapha dominated Tridoshaja condition, as Vata was responsible for Samkocha (2), Kapha for Shopha, and Pitta for Paka (3). So, all the three Doshas were responsible for the stenosis or the 
obstructing type of pathology of the fallopian tubes. Kshara-Taila is mentioned for Stree Roga Adhikar in Bharta Bhaishajya Ratanakara (4). But for present study, only Apamarga-Kshara was selected to prepare Taila to make the preparation of drug easier. The drug was selected due to its Vata Kapha Shamaka, Tridoshagna, having Ushna, Tikshna and sukshma properties, mentioned in Chakradutta (5), so that it could remove the blockage by reaching up to the minute channels.

\section{Preparation of the drug:}

The raw drugs were identified and authentified and powder microscopy was done in the pharmacognosy department, I.P.G.T. \& R.A., G.A.U., Jamnagar. After that the drug was prepared in the pharmacy of G.A.U., Jamnagar as per the classics and the prepared drugs were analyzed for pharmaceutical parameters in laboratory of Pharmaceutical chemistry, I.P.G.T. \& R.A., G. A. U. Jamnagar. Considering the organoleptic parameters, the drug had a yellow colour, aromatic odor, and thick consistency. The results of the physicochemical parameters such as loss on drying, specific gravity, refractive index, iodine value, saponification value, acid value were $0.55 \mathrm{w} / \mathrm{w}, 0.91,1.47,54.83$, 187.65 , and 9.13 respectively.

\section{Treatment Protocol:}

After cessation of menstruation, intra uterine Uttara Basti of Apamarga Kshara Taila was given in morning time with the consent of the patient. It was administered in the dose of $5 \mathrm{ml}$ for 6 days in each cycle with 2 consecutive cycles at three days interval (6). The patient was admitted for Uttar Basti and advised to have a light meal on the day of treatment; Abhyanga (massage) with Bala Taila (7) was done of lower abdomen and back. Thereafter, Nadi Sveda (fomentation) was performed on lower abdomen and back. Then, Yoni Prakshalana by some
Panchvalkala Kwath (8) of antiseptic property was performed to sterile the peri vaginal part. After this Purvakarma, the patient was asked to lie down in dorsal lithotomy position, on the operation table. The private part was cleaned with antiseptic solution. The vagina and cervix were visualized with the help of Sim's speculum (9) and an anterior vaginal wall retractor (10). The anterior lip of the cervix was held with the help of Allis' forceps (11) and uterine sounding was done. Then $5 \mathrm{ml}$ medicated oil was inserted with the help of Uttar Basti Cannula, already attached with $5 \mathrm{ml}$ syringe filled with Apamarga Kshara Taila and the patient was kept in head low position. The drug slowly injected above the level of the internal os. Instruments are removed and the patient was shifted to IPD ward. She was kept in head low position for at least 2 hours for better absorption of drug from vagina and to prevent any vasovagal shock. Patients were advised to avoid Intercourse during period of Uttar Basti treatment and also to avoid spice, over eating, fried food.

\section{Follow up study:}

Follow-up of patients for pregnancy or complications was carried out for 2 months after the completion of treatment. Any new complaint emerged during follow up period related to study was also noted.

\section{Observation and results:}

The observations of the study are presented in Figures 1 and Table-1-4. The $\mathrm{X}$-rays of patients with bilateral cornual and right cornual block are given in Figures 2-5. The effect of therapy is shown in Tables 5-8.

\section{Discussion}

While considering the history, it is established that in only $38.89 \%$ cases of tubal blockage, history of pelvic inflammatory disease was found. The total 
incidence of reproductive tract infection in study sample was not more than $44.45 \%$ (Table-1). It suggests that tubal blockage should be evaluated even if there are no apparent features or history of infection.

As an associated finding, the features of Artavakshaya, reported by Sushruta (12), among 18 patients registered, $100 \%$ were having Yoni Vedana (Dysmenorrhoea), Alpartava (Hypomenorrhoea) was found in $43.47 \%$ patients while Yathochitakale Adarshana was found in $25 \%$ of patients (Table-2).

There was not much significant difference observed in unilateral \& bilateral tubal blockage (Table-3). The $55.56 \%$ patients had unilateral tubal blockage, while $44.44 \%$ patients had bilateral tubal blockage. From patients having unilateral tubal blockage, $27.78 \%$ had right tubal blockage, while $27.78 \%$ had block in left tube. The most significant point emerged from this observation was the cornual tubal blockage. It was the most prevalent; as there were $22.22 \%$ right cornual and $16.66 \%$ left cornual blocks among all the registered patients of tubal blockage. Proximal tubal occlusion is mostly due to an inflammatory phenomenon, secondary to an ascending sexually transmitted disease, puerperal infection or septic abortion. It may also be associated to salpingitis isthmica nodusa, endometriosis, tubal polyposis, or other rare causes of endosalpingitis (13).

Another common site for block was found fimbrial with $5.56 \%$ in right and left tube each. The observations show that the factors related to cornual blocks were found more in study population, and hence, it was found commoner.

The findings of bilateral $(\mathrm{B} / \mathrm{L})$ tubal blockage showed $22.22 \% \mathrm{~B} / \mathrm{L}$ cornual blocks \& $11.11 \% \mathrm{~B} / \mathrm{L}$ fimbrial. Incidence of one cornual, other fimbrial was found in $11.11 \%$ patients each. These data positively support the fact that tubal blockage on sites other than cornual are less common (Figure-1).

\section{Interpretation of observations during \& after procedure}

As Apamarga Kshara Taila having Ushna-Tikshna properties used to remove blockage from tube. The lower abdominal pain was found in $25 \%$ of patient in tolerable limit. Among them 12.5\% patients were observed having pain more than 1 hour and $12.5 \%$ patients were observed having pain less than 1 hour (Table-4). Intolerable pain wasn't observed in any patient. Pain in lower abdomen isn't a bad sign; it denotes the contractile response of uterus to remove the blockage from tube.

\section{Interpretation of the results obtained:}

After analyzing the complicated condition of tubal infertility, tubal blockage was removed in $75 \%$ patient (12 patients), as evident by HSG. Rest four patients whose block couldn't open having other pathology (Table-5). Out of 12 patients, in whom tube was opened (Table6), 25\% (03 patients) conceived within follow up period.

The data of patients in whom block was removed but who could not conceive within follow up period it was observed that all the patients had some other factors involved (Table-7).

Among those other factors, Polycystic Ovarian Disease (PCOD) was detected in 02 patients; Anovulation was present in 03 patients, 01 patient had thyroid dysfunction and in 05 patients, male factor was unsatisfactory.

On the different Lakshana of Artavakshaya in 16 patients of, statistically significant result was observed in Alpata (Scanty menstruation or Hypomenorrhoea) i.e. $85.71 \%$, and highly significant i.e. $100 \%$ result was observed in Yoni Vedana (Dysmenorrhoea) \& Yathochitakale Adarshana (Oligomenorrhoea) (Table-8).

The most encouraging point is that, no feature of such type of infection or oil embolism was observed during or after procedure \& even in follow up period. 
Proper antiseptic care, before and after procedure does not allow any infection to grow.

These results are very encouraging for the Ayurvedic gynaecologists as well as those, who care for infertile population. Tila Taila has Anti inflammatory action due to its Vranashodhana, Vranapachana Karma (14-16), due to its Vyavayi and Sukshama Guna it spreads in minute channels and spreads easily. It pacifies Vata through its Snigdha property. The other contents in Apamarga Kshara Taila have Vatakaphagna, Lekhana property so it scrapes blockage from tube and also scraps the inner lining of endometrium. Thus, the inner fibrosed layer is removed. It is rejuvenated later, as endometrium has capacity to regenerate and antioxidant \& healing properties of various contents also help it for the same. Analyzing the effect of Uttar Basti on tubal blockage, the highly significant results show the potency of the drugs used and also the efficacy of Uttar Basti. Action of this procedure on various disorders is by both the ways, local as well as systemic. In case of tubal blockage, this effect seems to be more local than systemic. Other than that its specific role on uterus and reproductive tract is also mentioned as Garbhashayashodhana \& Yonishulaprashamana. These all the properties indicate towards its antiseptic as well as anti-inflammatory effects. Thus, it should be the best medium for any drug to reach in tubal cavity and remove the blockage.

It is not only the patency of tubal lumen, what is needed for the treatment of tubal infertility; normalization of the actions of fallopian tube is also another very important objective of the study. It can be achieved by pacifying the vitiation of Vata. Snigdha Guna of Taila is definitely helpful to relieve the abnormality generated by the Ruksha, Daruna \& Khara Guna of Vata. It restores the tonic contractions of tube and movement of cilia.

Figure 1: Number $(\%)$ of patients with various sites of tubal blockage $(n=18)$

\begin{tabular}{|r|r|r|} 
Both cornual & 22.22 \\
Both mid tubal \\
Both fimbrial
\end{tabular}


Table: 1 History of infection in 18 patients

\begin{tabular}{|l|l|l|}
\hline Infection & No. of patients & \% \\
\hline PID & 07 & 38.89 \\
\hline STD & 00 & 00 \\
\hline TB & 01 & 5.56 \\
\hline
\end{tabular}

Table: 2 Findings related to Artavakshaya Lakshana

\begin{tabular}{|l|l|l|}
\hline Artavakshaya Lakshana & No. of patients & \% \\
\hline Yathochitakale Adarshana & 4 & 25 \\
\hline Alpata & 7 & 43.75 \\
\hline Yoni Vedana & 16 & 100 \\
\hline
\end{tabular}

\begin{tabular}{|l|l|l|}
\hline &
\end{tabular}

Table 3: Findings of tubal blockage in patients by HSG $(n=18)$

\begin{tabular}{|l|l|l|}
\hline Tubal Blockage & No. of patients & $\%$ \\
\hline Unilateral & 10 & 55.56 \\
\hline Bilateral & 08 & 44.44 \\
\hline
\end{tabular}

Table 4: Observations during and after procedure

\begin{tabular}{|l|l|l|l|}
\hline Observation & No. of patients & $\%$ \\
\hline Abdominal Pain & & \\
\hline Severity & Tolerable & 04 & 25 \\
\hline
\end{tabular}




\begin{tabular}{|l|l|l|l|}
\hline & Intolerable & 00 & 00 \\
\hline \multirow{3}{*}{ Duration } & $<1$ hour & 02 & 12.5 \\
\cline { 2 - 4 } & $>1$ hour & 02 & 12.5 \\
\hline \multirow{2}{*}{ Qmount } & Spotting & 00 & 00 \\
\cline { 2 - 4 } & More & 00 & 00 \\
\hline & Fresh blood & 00 & 00 \\
\cline { 2 - 4 } & Dark blood & 00 & 00 \\
\hline
\end{tabular}

Table: 5 Logic behind some negative results

\begin{tabular}{|l|l|l|l|l|}
\hline Case & Type of Block & $\begin{array}{l}\text { Abnormalities } \\
\text { related to tube }\end{array}$ & $\begin{array}{l}\text { History of other } \\
\text { disease }\end{array}$ & Other \\
\hline $\mathbf{1}^{\text {st }}$ case & Right mid tubal & Very narrow tube & History of PID & - \\
\hline $\mathbf{2}^{\text {nd }}$ case & Both cornual & - & - & $\begin{array}{l}\text { Chronic \& elderly } \\
\text { age }\end{array}$ \\
\hline $\mathbf{3}^{\text {rd }}$ case & $\begin{array}{l}\text { Right Cornual, } \\
\text { Left Fimbrial }\end{array}$ & - & History of PID & - \\
\hline $\mathbf{4}^{\text {th }}$ case & Both cornual & - & - & Adhesion \\
\hline
\end{tabular}

Table: 6 Total effect of therapy

\begin{tabular}{|l|l|l|}
\hline No. of patients & Patients in whom block removed & \% \\
\hline 16 & 12 & 75 \\
\hline
\end{tabular}

Table: 7 Evaluation of patients who didn't conceive within follow up period after removal of block

\begin{tabular}{|l|l|l|}
\hline $\begin{array}{l}\text { No. of patients in whom } \\
\text { block was open, but there } \\
\text { was no conception }\end{array}$ & $\begin{array}{l}\text { Patients in whom no other } \\
\text { factor could be detected }\end{array}$ & $\begin{array}{l}\text { Patients in whom other } \\
\text { factors were involved }\end{array}$ \\
\hline 09 & 02 & 07 \\
\hline
\end{tabular}

Table: 8 Effect of therapy on associated symptoms.

\begin{tabular}{|l|l|l|}
\hline & & \\
Associated symptoms & No. of patients & $\%$ \\
\hline Yathochitakale Adarshanam & 04 & $100 \%$ \\
\hline Alpata & 06 & $85.71 \%$ \\
\hline Yonivedana & 16 & $100 \%$ \\
\hline
\end{tabular}

\section{Conclusion:}

The trial drugs Apamargakshara Taila gave highly significant results i.e. $75 \%$ in opening of fallopian tube. In this study, patency achieved in fimbrial block by above procedures has shown $83.33 \%$. In case of cornual block the result also found highly effective i.e. $76.92 \%$. Uttar Basti removes the blockage of tubal lumen by directly acting on obstruction and restores the normal endometrium. It restores the normal functions of cilia by stimulating it. It may break the tuboperitoneal adhesions, as it is observed with several studies that hysterosalpingography with oil based dye helps to break the adhesions \& it normalizes the tonic phasic contraction of muscles by pacification of Vata. It can be said that Uttar Basti procedure can be a standard treatment for 
management of female Infertility w.s.r. tubal blockage in routine Ayurvedic Gynecological practice.

\section{References}

1. Kanthi Bansal- Practical approach to infertility management, $1^{\text {st }}$ edition, New delhi, Jaypee publication, 2004, chapter 1, p.3-4.

2. Sharma H. Vidyotini Hindi Commentary, Kashyapa Samhita, Varanasi, Chaukhambha Samskrita Samsthana, 2012, Sutra 27/31, p.42

3. Shastry Ambikadutta, AyurvedaTattva-Sampidika Vyakhya, Sushrut Samhita, Varansi, Chaukhambha Sanskrita Samsthan, 2006, Sutra 17/12; p.94.

4. Nagindas Chhaganlal Shah, Bharta Bhaishajya Ratanakara, Ahemadabad, Unjha Ayurveda Pharmacy, 1937, 5th part, p. 533-534.

5. Indradeva Tripathi, Chakradutta, Vaidya Prabha Hindi Commentary, Varansi, Chaukhambha Sanskrita Bhavana, 2012, Karnaroga Chikitsa 57/25, p.339.

6. Atrideva Gupta, Vidyotini Hindi Commentary, Astanga Hridayam, Varanasi, Chaukhambha Samskrita Samsthana, 2005, Sutra 19/82; p.126.

7. Srikantha Murthy K.R. Vagbhata, Astanga Hridaya, Varanasi,
Chaukhambha Krishnadasa Academy, 2012, Chikitsa 21/73-81; p.510-511.

8. Sharangdharacharya, Sharangadhara Samhita, Tra. Himsagar Chandra Murty, Varanasi, Chaukhambha Surabharati series, 2007, Madhyama Khanda, p.40-9.

9. Harish Doshi, Comparison for obstetrics and Gynaecology examinations, India; Arihant Publishers; 2007.p.1-2.

10. Ibid, Comparison for Obstetrics and Gynaecology examinations.p.5.

11. Ibid, Comparison for Obstetrics and Gynaecology examinations.p.22-23.

12. Ibid, Sushrut Samhita, Sutra 15/12, p.76.

13. Vaclav Insler and Bruno Lunernfeld, Infertility: Male and Female, $2^{\text {nd }}$ edition, London; Churchill Livingstone; 1993.p.254

14. Srikantha Murthy KR. Bhavaprakasha of Bhavmishra. Vol. 2. Varanasi; Chaukhambha Krishnadasa Academy; 2002. Dhanya Varga, p.652.

15. Anonymous 1999, The Ayurvedic Pharmacopeia of India, Ministry of Health \& Family Welfare, dept. ofISM \& H, govt. of India, New Delhi, (API API, 4e)

16. Ibid, Sushrut Samhita, Sutra Sthana, 45/112, p.229-230. 